\title{
Mixing of Sputnik V and AstraZeneca COVID-19 vaccines
}

Emhemmed Ali Elgallal1 ${ }^{1}$, Inass A Sadawe ${ }^{2}$, Abdelmonam Hadi Elghobassa ${ }^{1}$, Abdulathim A A Alshoushan ${ }^{1}$, Salah M Bensaber ${ }^{3}$, Jamal Ali M. Elbakay ${ }^{3}$, Nisreen H Meiqal ${ }^{3}$, Massaud Salem Maamar ${ }^{4}$, Anton Hermann ${ }^{5}$ and Abdul M Gbaj ${ }^{3 *}$

${ }^{1}$ Food and Drug Control Centre (LFDA), Tripoli, Libya

${ }^{2}$ Medical Supply Organization (MSO), Tripoli, Libya

${ }^{3}$ Department of Medicinal Chemistry, Faculty of Pharmacy, University of Tripoli, Libya

${ }^{4}$ Zoology Department, Faculty of Science, Tripoli University, Libya

${ }^{5}$ Department of Biosciences, University of Salzburg, Salzburg, Austria

*Corresponding Author: Abdul M Gbaj, Professor of Genetics and Biochemistry, Department of Medicinal Chemistry, Faculty of Pharmacy, University of Tripoli, Libya.

\section{Received date: July 31, 2021; Accepted date: Augusł 18, 2021; Published date: Augusł 31, 2021}

Citation: Abdul M Gbaj, Emhemmed A Elgallal1, Inass A Sadawe, Abdelmonam H Elghobassa, Abdulathim A A Alshoushan, et al (2021). Mixing of Sputnik V and AstraZeneca COVID-19 vaccines. J. Clinical Research Notes. 2(1). DOI: 10.31579/2690-8816/034

Copyright: (C) 2021 Abdul M Gbaj. This is an open access article distributed under the Creative Commons Attribution License, which permits unrestricted use, distribution, and reproduction in any medium, provided the original work is properly cited.

\begin{abstract}
Background and Aim: The coronavirus disease 2019 (COVID-19) vaccine helps to develop immunity to SARS-CoV2 , the virus that causes COVID-19, in most cases preventing the disease. Although various brands of vaccines work in different modes, all COVID-19 vaccines prompt an immune reaction to make the body remembers how to protect from the virus in the future. The present study aims to evaluate the safety and the immune response for mixing of Sputnik V and AstraZeneca COVID-19 vaccines on mice.
\end{abstract}

Materials and Methods: Our experimental study was performed on mice weighing on average of 20 g, selected by random allocation. The mice were divided into four groups of 12 . Group one received a single dose of $0.5 \mathrm{ml} \mathrm{Sputnik} \mathrm{V}$ COVID-19 vaccine, group two received two doses of $0.5 \mathrm{ml}$ AstraZeneca COVID-19 vaccine, group three received two doses of $0.5 \mathrm{ml}$ Sputnik V together with $0.5 \mathrm{ml}$ AstraZeneca COVID-19 vaccine and group four received two doses of 0.5 $\mathrm{ml}$ of $0.9 \% \mathrm{NaCl}$.

Results: Our study shows that mixing of Sputnik V and AstraZeneca COVID-19 vaccines is safe and induces good immunity for mice.

Conclusion: Mixing of Sputnik V and AstraZeneca COVID-19 vaccines creates no problems and provides good immunity to mice and may be an interesting technique to help to overcome shortcomings of one or the other vaccine. Further toxicity studies are required to assess potential hazards for humans to evaluate the histopathological characteristics.

Keywords: sputnik V COVID-19 vaccine; astra zeneca COVID-19 vaccine; mice; coronavirus disease (COVID-19); RNA; Pfizer-BioNTech; SARS-CoV-2; Libya; cross-priming; spike

\section{Introduction}

Coronavirus Disease 2019 (COVID-19) pandemic causes the severe acute respiratory syndrome coronavirus-2 (SARS-CoV-2). The plague has affected almost every side of human life and will persist to do so until most of the population is vaccinated. SARS-CoV-2 infection starts with the attachment of the trimeric "spike" glycoprotein to the virion surface binding to angiotensin-converting enzyme 2 , allowing viral entrance and starting of viral replication $[1,2]$. Several vaccine platforms were developed to generate a rapid emergency response. The main types of COVID-19 vaccines currently available are: messenger RNA (mRNA) vaccine (Pfizer-BioNTech) [3], vector vaccine (AstraZeneca and the University of Oxford, Sputnik V) [4], Protein subunit vaccine (Novavax) and inactivated virus (Sinovac Biotech) [5]. Most authorized vaccines need two doses administered at three or even months separation time. Several European countries and Canada are now recommending a different vaccine as the second dose for some patients and they found such approach could be beneficial. In addition, in three recent studies, researchers have established that following one dose of the vaccine made by AstraZeneca with a dose of the Pfizer-BioNTech vaccine produces powerful immune responses, as measured by blood tests [6]. Two of the studies even recommend mixed vaccine application which was at least as 
protective as two doses of the Pfizer-BioNTech product [6]. Due to short supplies of Sputnik V COVID-19 vaccine component II to Libya the study was required to investigate the possibility of having a different vaccine for the second dose.

\section{Materials and methods}

\section{Experimental animals}

Swiss Albino male mice $(18 \pm 3 \mathrm{~g})$ were used for experiments. In order to reduce the contact caused by environmental alterations and handling during behavioral studies, mice were acclimatized to the Laboratory Animal Holding Center and laboratory surroundings for three days and at least one hour before the experiments, respectively. Mice were kept under standard conditions with food (low protein diet) and water available ad libitum. The animals were housed six per cage in a light-controlled room $(12 \mathrm{~h}$ light/dark cycle, light on $07: 00 \mathrm{~h})$ at $27^{\circ} \mathrm{C}$ and $65 \%$ relative humidity. All experiments were carried out between 11:30 and 14:00 h. Each test group consisted of 12 mice, and each mouse was used only once. All animal experiments were conducted according to guidelines set by the Institutional Animal Ethics Committee of University of Tripoli.

\section{Clinical and necropsy Observations}

This study represents one arm of the safety evaluation program for the two vaccines and was designed to assess local tolerance to acute toxicity. The aim was to evaluate these parameters following the administration of the proposed human vaccine dose. The mice were divided into four groups of 12. Group one received single dose of $0.5 \mathrm{ml}$ Sputnik V COVID-19 vaccine, Group two received two doses of $0.5 \mathrm{ml}$ AstraZeneca COVID19 vaccine and the second dose was given after 21 days, group three received two doses of $0.5 \mathrm{ml}$ (human dose) Sputnik V and $0.5 \mathrm{ml}$ (human dose) AstraZeneca COVID-19 vaccines after 21 days and group four (control) received two doses of $0.5 \mathrm{ml}$ of $0.9 \% \mathrm{NaCl}$. Mice were examined every day for 40 days. Any signs of ill health were recorded daily. Blood samples for IgM and IgG were taken from animals in day 14 and day 35 after first dosing. At necropsy a full macroscopic examination was performed on each animal. Organs macroscopically examined were spleen, lungs, liver, kidney, heart, brain, testes, and ovaries.

\section{Statistical analysis}

The difference among various treated groups and the control group were analyzed using one-way-ANOVA followed using unpaired Student's t test. The results were expressed as the mean \pm SEM of the number of experiments done, with $\mathrm{p}<0.05$ indicating a significant difference between groups. All $\mathrm{p}$ values reported are for a one-tailed test. The significance level was chosen at $\alpha=0.05$.

\section{Results and discussion}

None of the mice used in the study showed any sign of abnormality or ill health throughout the 42 days post-immunization observation for the four groups. At the necropsies no macroscopic treatment related changes were observed. Antibody binding the SARS-CoV-2 spike protein was induced by vaccination, and, as expected, the temporal induction of anti-spike IgM was faster than that of IgG.

The potential vaccine combinations of Sputnik V and AstraZeneca COVID-19 vaccines have been tested on mice. This primary result of mixing vaccines proves safety and effectiveness and could speed the effort to protect people. This is consistent with the implications by Cristóbal Belda-Iniesta, a clinical research consultant at the Carlos III Health Institute. Governments might instantaneously distribute new doses without worrying about setting aside second shots of explicit vaccines to provide people weeks or months later. In addition, Europe and Canada have an added incentive [6]. Millions of people there received an initial dose of the AstraZeneca vaccine before governments recommended younger aged groups to avoid it because of the risk of a rare clotting disorder. They were left wondering what to do next: get a second dose or switch to a different vaccine like Sputnik V which may help sorting the issue.

The capability to mix and match vaccines might make vaccination programs more flexible and may speed up the process and reduce the impact of any supply-chain disruptions [7]. AstraZeneca is conducting a similar study of combining its COVID-19 vaccine with the Russian coronavirus vaccine. Sputnik V, uses harmless viruses to carry components of the coronavirus into cells. Sputnik V, which has greater than $90 \%$ efficacy against COVID-19, is a heterologous prime-boost vaccine, consisting of different viral components in the first and second doses [8].

Our study is a trial of combining two vaccines which could strengthen immune responses by connecting the best features of each. This appears chiefly beneficial since vaccine developers are combating coronavirus variants that seem to be partly resistant to certain immune responses. Different reactions to two different vaccines could be more procreative compared to what either vaccine can accomplish on its own. These possibilities remain to be proven experimentally on human for COVID19.

AstraZeneca and Sputnik produce DNA vaccines based on similar mechanisms and consist of delivering genes or fragments of it, encoding immunogenic antigens, to the host cells by using DNA plasmids as a vector. This approach induces both humoral and cell-mediated immune responses efficiently [9]. The formulation of both vaccines is made such that the genetic material is translocated to the host cell nucleus. Once it reaches there, the mammalian promoter present in its vector structure is activated, triggering the transcription of the gene used for the vaccine throughout the host's cellular machinery. The antigen-presenting cells (APCs) are the major target cells to receive the genetic material. In addition, myocytes are reported to play a vital role. After translation of the translocated gene into a protein or protein fragment, it is processed into peptides which bind to major histocompatibility complexes (MHC) class I or II. Cells other than APC, such as the myocytes, use MHC-I for antigen presentation, and APC, such as dendritic cells (DCs), can use MHC-II, resulting in cross-priming and presentation of antigens to both CD4+ and CD8+ T cells [10,11]

\section{Conclusion}

Our study shows that AstraZeneca vaccine given as second dose to mice after Sputnik V COVID-19 vaccination-produces an immune response with no side-effects.

\section{References}

1. Hsih WH, Cheng MY, Ho MW, Chou CH, Lin PC, Chi CY, Liao WC, Chen CY, Leong LY, Tien N, Lai HC, Lai YC, Lu MC. (2020). Featuring COVID-19 cases via screening symptomatic patients with epidemiologic link during flu season in a medical center of central Taiwan. J Microbiol Immunol Infect 2020; 53(3):459-466

2. Peric ̃̃ s JM, Hernandez-Meneses M, Sheahan TP, Quintana E, Ambrosioni J, Sandoval E, Falces C, Marcos MA, Tuset M, Vilella A, Moreno A, Miro JM. (2020). COVID-19: from epidemiology to treatment. Eur Heart J 2020; 41(22):2092-2112.

3. Krammer F. (2020). SARS-CoV-2 vaccines in development. Nature 2020; 586(7830):516-527.

4. Knoll MD, Wonodi C. (2021). Oxford-AstraZeneca COVID-19 vaccine efficacy. Lancet 2021; 397(10269):72-74.

5. Zhonghua Yu Fang Yi Xue Za Zhi (2020). [Technical guidelines for seasonal influenza vaccination in China (2019-2020)] ; 54(1):21-36. 
6. Vogel G. (2021). Mixing vaccines may boost immune responses. Science 2021; 372(6547):1138.

7. Ledford H. (2021). Could mixing COVID vaccines boost immune response? Nature 2021; 590(7846):375-376.

8. Logunov DY, Dolzhikova IV, Zubkova OV, Tukhvatulin AI, Shcheblyakov DV, Dzharullaeva AS, Grousova DM, Erokhova AS, Kovyrshina AV, Botikov AG, Izhaeva FM, Popova O, Ozharovskaya TA, Esmagambetov IB, Favorskaya IA, Zrelkin DI, Voronina DV, Shcherbinin DN, Semikhin AS, Simakova YV, Tokarskaya EA, Lubenets NL, Egorova DA, Shmarov MM, Nikitenko NA, Morozova LF, Smolyarchuk EA, Kryukov EV, Babira VF, Borisevich SV, Naroditsky BS, Gintsburg AL.(2021). Safety and immunogenicity of an rAd26 and rAd5 vector-based heterologous prime-boost COVID-19 vaccine in two formulations: two open, non-randomised phase $1 / 2$ studies from Russia. Lancet 2020; 396(10255):887-897.

9. Silveira MM, Oliveira TL, Schuch RA, McBride AJA, Dellagostin OA, Hartwig DD. (2017). DNA vaccines against leptospirosis: A literature review. Vaccine 2017; 35(42):55595567.

10. Ingolotti M, Kawalekar O, Shedlock DJ, Muthumani K, Weiner DB. (2010). DNA vaccines for targeting bacterial infections. Expert Rev Vaccines 2010; 9(7):747-763.

11. Coban C, Kobiyama K, Jounai N, Tozuka M, Ishii KJ. (2013). DNA vaccines: a simple DNA sensing matter? Hum VaccinImmunother 2013; 9(10):2216-2221.
This work is licensed under Creative Commons Attribution 4.0 License

\section{To Submit Your Article Click Here: Submit Manuscript}

DOI: $10.31579 / 2690-8816 / 034$
Ready to submit your research? Choose Auctores and benefit from:

* fast, convenient online submission

* rigorous peer review by experienced research in your field

* rapid publication on acceptance

* authors retain copyrights

* unique DOI for all articles

* immediate, unrestricted online access

At Auctores, research is always in progress.

Learn more auctoresonline.org/journals/clinical-research-notes- 